\title{
Evaluation of White Blood Cell- and Platelet-Derived Cytokine Accumulation in MIRASOL-PRT-Treated Platelets
}

\author{
Susanne M. Picker Alexander Steisel Birgit S. Gathof \\ Transfusion Medicine, University of Cologne, Germany
}

\author{
Key Words \\ Pathogen reduction - Mirasol-PRT - Ccytokines . \\ Transfusion reaction
}

\section{Summary}

Background: Soluble mediators in platelet concentrates (PCs) released from contaminating white blood cells (WBCs) and platelets (PLTs) themselves are supposed to promote allergic and non-hemolytic febrile transfusion reactions in the recipient. Pathogen reduction technologies (PRTs) prevent replication and proliferation of pathogens as well as of WBCs, and may reduce cytokine accumulation in PCs during storage and prevent adverse events after PLT transfusion. On the other hand, such treatments may also lead to increased cytokine production by stimulation of WBCs or PLTs due to the photochemical or photodynamical process itself. Material and Methods: 12 triple-dose PLT apheresis collections were leukoreduced by the process-controlled leukoreduction system of the Trima Accel machine and split into 3 units undergoing Mirasol-PRT treatment (M) or gamma irradiation (X) or remaining untreated (C). During storage for up to 7 days, PLT activation, WBC-derived Th-1/2, and inflammatory as well as PLT-derived cytokines were measured by cytometric bead array and enzymelinked immunosorbent assay, respectively. Results: Independent of treatment, all PLT products exhibited low levels of WBC-associated cytokines near or below assay detection limits. WBC-associated cytokines were not elevated by $\mathrm{Mi}-$ rasol-PRT treatment. PLT-derived cytokines were detected at higher levels and increased significantly during storage in all units. Most likely due to higher PLT activation, M units showed significantly higher levels of PLT-derived cytokines compared to untreated and gamma-irradiated units on day 5 of storage. Conclusion: In all PCs, PLTs themselves were the main source of cytokine release. Mirasol-PRT treatment was associated with a significantly increased PLT activation and accumulation of PLT-derived cytokines during storage, without affecting WBC-derived cytokines relative to controls.

\author{
Schlüsselwörter \\ Pathogenreduktion · Mirasol-PRT · Zytokine . \\ Transfusionsreaktion
}

\section{Zusammenfassung}

Hintergrund: Aus Leukozyten oder Thrombozyten stammende Mediatoren in Plättchenkonzentraten können allergische und nicht hämolytische febrile Transfusionsreaktionen im Empfänger hervorrufen. Da Pathogenreduktionstechniken (PRT) die Replikation und Proliferation von Pathogenen und Leukozyten unterbinden, könnten die mit der Zytokinanreicherung verbundenen unerwünschten Transfusionsereignisse verhindert werden. Andererseits ist es denkbar, dass PRT die leukozytäre und thrombozytäre Zytokinproduktion durch photodynamische oder photochemische Stimulation dieser Zellen erhöht. Material und Methoden: 12 leukozytendepletierte Dreifachplättchenkonzentrate wurden durch Apherese mit dem Trima-Accel-Zellseparator gewonnen. Gleich nach Auftrennung wurde eine Einheit der MirasolPRT-Behandlung unterzogen (M), die beiden anderen blieben entweder unbehandelt (C) oder wurden mit 30 Gy gammabestrahlt (X). Während 7 Tagen Lagerung wurden Plättchenaktivierung, leukozytäre Th-1/2 bzw. inflammatorische Zytokine sowie plättcheneigene Zytokine untersucht. Ergebnisse: Ungeachtet der Behandlung wiesen alle Einheiten nur sehr geringe Konzentrationen leukozytärer Zytokine auf. Höhere Konzentrationen wurden für Plättchenzytokine gemessen. Diese stiegen in allen Einheiten mit wachsender Lagerungsdauer an. Wahrscheinlich aufgrund höherer Plättchenaktivierung lag die Konzentration der M-Einheiten ab Tag 5 der Lagerung signifikant höher als die der unbehandelten und bestrahlten Einheiten. Schlussfolgerung: In allen Einheiten stammten die Zytokine hauptsächlich aus den Plättchen selbst. Die Mirasol-PRT-Behandlung führte zu einem signifikanten Anstieg der Plättchenaktivierung und dadurch zu vermehrter Freisetzung von Plättchenzytokinen. Leukozytäre Zytokine blieben im Vergleich zu unbehandelten und bestrahlten Kontrollen unbeeinflusst.

\begin{tabular}{ll}
\hline KARGER & $\oplus$ 2009 S. Karger GmbH, Freiburg \\
Fax +497614520714 & Accessible online at: \\
Information@Karger.de & www.karger.com/tmh \\
www.karger.com &
\end{tabular}

\section{KARGER} www.karger.com
Dr. Susanne M. Picker 


\section{Introduction}

White blood cell (WBC)- and platelet (PLT)-derived soluble mediators in PLT concentrates (PCs) are involved in adverse events after PLT transfusion [1-4] and have been shown to be elevated in clinical conditions that are associated with increased thrombotic risk [5]. Plasma removal [1, 2] and prestorage leukoreduction [6-8] lower the frequency of febrile non-hemolytic reactions after PLT transfusion, whereas the incidence of allergic reactions has not been altered after the introduction of WBC reduction $[6,8]$, which highlights the role of PLT-derived cytokines. Some of these cytokines, particularly CCL5 (RANTES), have previously been reported to be involved in non-hemolytic, allergic, or pro-inflammatory transfusion reactions of leukoreduced products due to their ability to attract and stimulate human eosinophils and to induce histamine release from human basophils [1-3, 9-13].

Pathogen reduction technologies (PRTs) such as the Mirasol-PRT system using riboflavin (vitamin $\mathrm{B}_{2}$ ) in combination with ultraviolet (UV) light (Caridian BCT Biotechnologies, Lakewood, CO, USA) induce nucleic acid damage. This treatment affects all DNA- and RNA-containing organisms and cells (i.e. WBCs) and thus may impair new synthesis of soluble mediators $[14,15]$. The fact that human PLTs contain mRNA and mitochondrial DNA involved in respiration as well as in cytokine synthesis $[16,17]$ raises the question of whether or not PRT may lower cytokine release in stored PCs [18]. This study evaluates WBC-derived Th-1/2 (IL-2, IL-4, IL-5, IL-10, TNF, IFN- $\gamma$ ) and inflammatory cytokines (IL-6, IL-8, IL-1 $\beta$, IL-12p70) as well as PLT-associated cytokines (CCL3 = macrophage inflammatory peptide MIP-1 $\alpha$, CCL5 = RANTES, CXCL4 = PLT factor 4 , TGF- $\beta 1=$ transforming growth factor beta 1) and compares results obtained from Mirasol-PRTtreated PCs to gamma-irradiated and untreated control PCs from the same donors.

\section{Material and Methods}

Preparation and Storage of PLT Concentrates

After passing eligibility criteria based on German [19] and European [20 requirements for PLT donation, a total of 12 triple-dose collections were performed using the Trima Accel apheresis collection device, vs. 5.0 (Caridian BCT Biotechnologies). Acid citrate dextrose with adenine (ACDA) was used as anticoagulant for all collections. The collection targets per procedure were at least $8.5 \times 10^{11}$ PLTs in at least $510 \mathrm{ml}$ autologous plasma to facilitate the division into 3 aliquots (bags). The whole collection units averaged $713.6 \pm 13 \mathrm{ml}$ and $1,267 \pm 117 \times 10^{9} \mathrm{PLTs} / 1$ (corresponding to a mean collection dose of $9.0 \times 10^{11}$ ) and were kept undisturbed for $2 \mathrm{~h}$ at ambient temperature prior to splitting and subsequent processing to allow dissociation of any PLT aggregates. All units were leukodepleted by the process-controlled leukoreduction system and suspended in autologous plasma without addition of PLT additive solution (PAS). Immediately after splitting, single units were treated with Mirasol-PRT (M), remained untreated (C), or were exposed to 30-Gy gamma irradiation (X). In order to ensure comparable storage conditions for all units, the 1-L ELP ${ }^{\mathrm{TM}}$ bag (extended Life Platelet, Caridian BCT Biotechnologies) was used for all 3 types of PLT concentrates (C, M, X). All 36 single units were stored for an additional 7 days at $22 \pm 2{ }^{\circ} \mathrm{C}$ on a flatbed agitator (Helmer Laboratories, Noblesville, IN, USA) running at 50-60 agitations per minute.

\section{Treatment with the MIRASOL-PRT System}

Mirasol-PRT treatment was performed as previously described [21-24] immediately after splitting, on the day of collection (defined as day 0 ).

\section{Sampling}

Day-0 samples were taken prior to apheresis from each donor by direct venipuncture. Additional samples were taken aseptically from each storage bag on days 1 (to examine the immediate effects of PRT treatment), 5 , and 7 (to examine longer-term effects). Except for the analysis of PLT count, lactate dehydrogenase $(\mathrm{LDH})$ release and $\mathrm{p}$-selectin expression (immediate analysis), all samples were centrifuged (see below) and the supernatants frozen at $-70{ }^{\circ} \mathrm{C}$ until analysis by ELISA (PLT-derived cytokines) or cytometric bead array (WBC-derived cytokine). Analyses were completed within $6 \mathrm{~h}$ after thawing.

\section{Laboratory Methods}

Total PLT counts were determined using an automated electronic particle counter (Sysmex K1000, Sysmex, Hamburg, Germany). Culturing using the BacTec ${ }^{\circledR}$ System (BD Biosciences, San Jose, CA, USA), residual WBCs and RBCs, LDH release, and p-selectin expression were performed as described previously [25]. Samples for cytokine analysis were centrifuged at $1,000 \times \mathrm{g}$ for $30 \mathrm{~min}$ at room temperature and the supernatants were frozen at $-70{ }^{\circ} \mathrm{C}$. Commercially available ELISA kits were used according to the manufacturers' instructions (R and D Systems Inc., Abington, UK, for analysis of CCL3 (MIP-1 $\alpha$ ), CCL5 (RANTES), TGF- $\beta 1$; Hyphen BioMed, Neuville-sur-Oise, France, for analysis of CXCL4 (PLT factor 4)). Detection limits ranged from 2 to $100 \mathrm{pg} / \mathrm{ml}$. WBC-associated cytokines were analyzed by flow cytometry using cytometric bead arrays (Human Inflammation and Th2/Th2 cytokine kits, BD Biosciences). Assay sensitivities ranged from $1.9 \mathrm{pg} / \mathrm{ml}$ (IL-12p70) to $7.2 \mathrm{pg} / \mathrm{ml}$ (IL-1 $\beta$ ).

\section{Statistical Analysis}

The results are expressed as mean \pm one standard deviation. Statistical analysis was conducted comparing all 3 types of units with the KruskalWallis test (SPSS 15.0 for Windows, SPSS Software GmbH, Munich, Germany). In the case of significant differences $(\mathrm{p}<0.05)$, post-hoc paired comparisons were made with the Mann-Whitney-U-test. Here, according to Bonferroni, a p value $<0.017$ was related to a significance level of $5 \%$.

\section{Results}

\section{Apheresis Characteristics}

Apheresis procedures were well tolerated by all study subjects. All unit cultures were negative after 16 days of incubation under aerobic and anaerobic conditions. Contaminating WBCs and RBCs averaged mean values of $0.46 \pm 0.47 \times 10^{6}$ and 0.81 $\pm 0.17 \times 10^{9}$ per unit, respectively (table 1 ). Unit volumes and PLT doses recorded immediately after splitting ranged from $228.7 \mathrm{ml}$ to $245.9 \mathrm{ml}$ and from $2.3 \times 10^{11}$ to $3.6 \times 10^{11}$, without proving statistical significance between the study groups.

\section{Storage-Related Evolution of PLT Count, LDH Release, and PLT Activation}

The addition of riboflavin $(27.0 \pm 3.5 \mathrm{ml})$ to $\mathrm{M}$ units increased the PC volume and lowered the PLT concentration 
Table 1. Apheresis and storage characteristics of the study PCs (volume and PLT dose not corrected for volume removal by sampling)

\begin{tabular}{|c|c|c|c|c|}
\hline Variable & Day 0 & Day 1 & Day 5 & Day 7 \\
\hline \multicolumn{5}{|c|}{ Residual WBCs $\left(\times 10^{6} /\right.$ unit $)$} \\
\hline$M(n=12)$ & $0.46 \pm 0.47^{*}$ & not done & not done & not done \\
\hline $\mathrm{C}(\mathrm{n}=12)$ & $0.46 \pm 0.47 *$ & not done & not done & not done \\
\hline $\mathrm{X}(\mathrm{n}=12)$ & $0.47 \pm 0.48^{*}$ & not done & not done & not done \\
\hline \multicolumn{5}{|c|}{ Residual RBCs (× $10^{\%} /$ unit $)$} \\
\hline$M(n=12)$ & $0.81 \pm 0.17^{*}$ & not done & not done & not done \\
\hline$C(n=12)$ & $0.80 \pm 0.16^{*}$ & not done & not done & not done \\
\hline $\mathrm{X}(\mathrm{n}=12$ & $0.81 \pm 0.17^{*}$ & not done & not done & not done \\
\hline \multicolumn{5}{|l|}{ Volume (ml) } \\
\hline$M(n=12)$ & $237.7 \pm 4.4^{*}$ & $242.4 \pm 10.2^{\mathrm{a}, \mathrm{b}}$ & $224.6 \pm 10.3^{\mathrm{a}, \mathrm{b}}$ & $207.8 \pm 10.8^{\mathrm{a}, \mathrm{b}}$ \\
\hline $\mathrm{C}(\mathrm{n}=12)$ & $236.9 \pm 5.1^{*}$ & $218.4 \pm 4.5^{\mathrm{c}}$ & $198.4 \pm 4.0^{c}$ & $180.9 \pm 4.3^{\mathrm{c}}$ \\
\hline $\mathrm{X}(\mathrm{n}=12$ & $237.7 \pm 4.6^{*}$ & $219.0 \pm 4.2^{\mathrm{c}}$ & $199.1 \pm 4.2^{\mathrm{c}}$ & $181.3 \pm 4.3^{\mathrm{c}}$ \\
\hline \multicolumn{5}{|c|}{ PLT concentration $\left(\times 10^{9} / 1\right)$} \\
\hline$M(n=12)$ & $1,071 \pm 105^{* * a, b}$ & $1,021 \pm 124^{\mathrm{a}, \mathrm{b}}$ & $1,012 \pm 111^{\mathrm{a}, \mathrm{b}}$ & $1,007 \pm 110^{\mathrm{a}, \mathrm{b}}$ \\
\hline$C(n=12)$ & $1,244 \pm 131 * * \mathrm{c}$ & $1,232 \pm 128^{\mathrm{c}}$ & $1,245 \pm 120^{\mathrm{c}}$ & $1,226 \pm 123^{\mathrm{c}}$ \\
\hline$X(n=12$ & $1,249 \pm 134 * * \mathrm{c}$ & $1,251 \pm 123^{c}$ & $1,245 \pm 136^{\mathrm{c}}$ & $1,226 \pm 127^{\mathrm{c}}$ \\
\hline \multicolumn{5}{|c|}{ PLT dose ( $\times 10^{11}$ /unit $)$} \\
\hline$M(n=12)$ & $2.84 \pm 0.32 * *$ & $2.48 \pm 0.35$ & $2.28 \pm 0.31$ & $2.10 \pm 0.28$ \\
\hline $\mathrm{C}(\mathrm{n}=12)$ & $2.95 \pm 0.32 * *$ & $2.69 \pm 0.28$ & $2.47 \pm 0.24$ & $2.22 \pm 0.23$ \\
\hline$X(n=12$ & $2.97 \pm 0.35^{* *}$ & $2.74 \pm 0.29$ & $2.48 \pm 0.29$ & $2.22 \pm 0.26$ \\
\hline \multicolumn{5}{|c|}{ LDH release (U/l) } \\
\hline $\mathrm{M}(\mathrm{n}=12)$ & $106 \pm 12 * * a, b$ & $104 \pm 14^{\mathrm{a}, \mathrm{b}}$ & $185 \pm 64$ & $152 \pm 15$ \\
\hline $\mathrm{C}(\mathrm{n}=12)$ & $122 \pm 16^{* * c}$ & $125 \pm 15^{\mathrm{c}}$ & $150 \pm 15$ & $165 \pm 31$ \\
\hline $\mathrm{X}(\mathrm{n}=12$ & $127 \pm 9 * * \mathrm{c}$ & $131 \pm 12^{\mathrm{c}}$ & $157 \pm 19$ & $162 \pm 21$ \\
\hline \multicolumn{5}{|c|}{ P-selectin expression, \% } \\
\hline$M(n=12)$ & $28.5 \pm 15.3^{* *}$ & $38.4 \pm 13.8^{\mathrm{a}, \mathrm{b}}$ & $69.7 \pm 11.0^{\mathrm{a}, \mathrm{b}}$ & $82.4 \pm 10.7^{\mathrm{a}, \mathrm{b}}$ \\
\hline$C(n=12)$ & $16.8 \pm 5.1 * *$ & $15.6 \pm 7.8^{\mathrm{c}}$ & $35.4 \pm 9.5^{\mathrm{c}}$ & $46.2 \pm 9.3^{c}$ \\
\hline$X(n=12$ & $17.0 \pm 6.5^{* *}$ & $16.0 \pm 7.9^{c}$ & $38.0 \pm 10.1^{\mathrm{c}}$ & $48.6 \pm 9.5^{\mathrm{c}}$ \\
\hline
\end{tabular}

*After splitting and before PRT or gamma irradiation.

**After splitting and riboflavin addition and before illumination.

${ }^{\text {a}}$ Significant compared to untreated units (C).

'Significant compared to gamma-irradiated units (X).

'Significant compared to PRT-treated units (M).

$\left(\times 10^{9} / 1\right)$ compared to untreated and gamma-irradiated controls on day 1 (table 1 ). No difference in volume reduction rates was observed, confirming that equal volumes were removed by sampling in all units. Moreover, calculating total PLT dose $\left(\times 10^{11} /\right.$ unit $)$ from PLT concentration $\left(\times 10^{9} / 1\right)$ and $\mathrm{PC}$ volume $(\mathrm{ml})$, no significant differences were observed between $\mathrm{M}$ units and their counterparts $(\mathrm{C}, \mathrm{X})$, suggesting that PRT treatment did not induce relevant cell loss. Initial LDH levels were lower in $\mathrm{M}$ units compared to controls, most likely due to the dilution effect after riboflavin addition. LDH release increased moderately during storage in all units. No significant changes in LDH release were observed compared to untreated or irradiated units, suggesting that PRT treatment did not induce cell lysis. The percentage of PLTs expressing p-selectin on their surface increased progressively throughout storage in all types of units. After PRT treatment (day 1) and throughout storage, p-selectin expression in $\mathrm{M}$ units was significantly higher than in untreated and gamma-irradiated units.

\section{Cytokine Accumulation during Storage}

Levels of Th-1/2 and inflammatory WBC-derived cytokines were close to or below detection limits in all PCs throughout 7 days of storage (table 2). Overall, the levels of these cytokines were not elevated by Mirasol-PRT treatment (figs. 1, 2). Unlike WBC-related cytokines, high levels of PLT-derived cytokines were detected in supernatants of all stored PCs independent of treatment (table 2). Because of lower PLT concentration $\left(\times 10^{9} / 1\right)$ after riboflavin addition and Mirasol-PRT treatment, the measured total cytokine concentration was corrected for PLT number at the time of sampling. Except for MIP-1 $\alpha$, all PLT-derived cytokines examined increased during storage and appeared to reach a plateau after 5-7 days. After Mirasol-PRT treatment, accumulation of PLT-derived cytokines during storage was significantly higher compared to untreated and gammairradiated control units (fig. 3). No significant differences in the overall or corrected accumulation rate of IL- 1 and IL- 8 released from both WBCs and PLTs [26, 27] was detected between Mirasol-PRT-treated and untreated/gamma units (fig. 4). 
Table 2. Cytokine concentration in donors immediately before apheresis and in study PCs after 7 days of storage

\begin{tabular}{|c|c|c|c|c|}
\hline & \multirow{2}{*}{$\begin{array}{l}\text { Cytokine baseline } \\
\text { levels of donors }\end{array}$} & \multicolumn{3}{|c|}{ Cytokine levels in study PCs after 7 days of storage } \\
\hline & & $M(n=12)$ & $C(n=12)$ & $X(n=12)$ \\
\hline \multicolumn{5}{|c|}{ WBC-associated cytokines (Th-1/2) } \\
\hline IL-2, pg/ml & $4.37 \pm 1.26$ & $4.15 \pm 1.40$ & $3.47 \pm 1.02$ & $4.12 \pm 1.68$ \\
\hline $\mathrm{IL}-4, \mathrm{pg} / \mathrm{ml}$ & $1.89 \pm 0.44^{\mathrm{a}}$ & $1.76 \pm 0.34^{\mathrm{a}}$ & $1.40 \pm 0.22^{\mathrm{c}, \mathrm{d}}$ & $1.67 \pm 0.32$ \\
\hline $\mathrm{IL}-5, \mathrm{pg} / \mathrm{ml}$ & $1.46 \pm 0.23$ & $1.51 \pm 0.15$ & $1.39 \pm 0.16$ & $1.27 \pm 0.43$ \\
\hline IL-10, $\mathrm{pg} / \mathrm{ml}$ & $2.48 \pm 0.37$ & $2.49 \pm 0.47$ & $2.14 \pm 0.39$ & $2.14 \pm 0.36$ \\
\hline $\mathrm{TNF}, \mathrm{pg} / \mathrm{ml}$ & $1.22 \pm 0.72$ & $1.59 \pm 0.26^{\mathrm{a}}$ & $1.02 \pm 0.63^{\mathrm{c}}$ & $1.37 \pm 0.49$ \\
\hline IFN- $\gamma, \mathrm{pg} / \mathrm{ml}$ & $6.80 \pm 4.05$ & $6.46 \pm 2.67^{\mathrm{a}}$ & $3.33 \pm 2.00^{\mathrm{c}}$ & $4.95 \pm 2.42$ \\
\hline \multicolumn{5}{|c|}{ WBC-associated cytokines (inflammatory) } \\
\hline IL-6, pg/ml & $2.00 \pm 0.97$ & $2.23 \pm 0.60$ & $2.39 \pm 1.25$ & $1.98 \pm 0.77$ \\
\hline IL-8, pg/ml & $2.32 \pm 0.59$ & $3.08 \pm 0.74$ & $3.11 \pm 1.33$ & $2.73 \pm 1.54$ \\
\hline $\mathrm{IL}-1 \beta, \mathrm{pg} / \mathrm{ml}$ & $3.34 \pm 1.08$ & $3.48 \pm 1.30$ & $3.29 \pm 1.47$ & $2.92 \pm 1.03$ \\
\hline IL-12p70, pg/ml & $0.98 \pm 0.97^{\mathrm{c}}$ & $1.87 \pm 0.83^{\mathrm{b}, \mathrm{d}}$ & $1.85 \pm 1.30$ & $1.48 \pm 0.86^{\mathrm{c}}$ \\
\hline \multicolumn{5}{|l|}{ PLT-associated cytokines } \\
\hline CCL3/MIP-1 $\alpha, p g / m l$ & $55.4 \pm 1.5^{\mathrm{a}, \mathrm{b}}$ & $54.3 \pm 8.0^{\mathrm{a}, \mathrm{b}}$ & $46.4 \pm 6.5^{\mathrm{c,d}}$ & $46.2 \pm 6.1^{\mathrm{c}, \mathrm{d}}$ \\
\hline TGF- $\beta, \mathrm{ng} / \mathrm{ml}$ & $1.1 \pm 0.1^{\mathrm{a}, \mathrm{b}, \mathrm{c}}$ & $22.7 \pm 5.1^{\mathrm{a}, \mathrm{d}}$ & $13.1 \pm 4.9^{\mathrm{c}, \mathrm{d}}$ & $16.0 \pm 6.6^{\mathrm{d}}$ \\
\hline $\mathrm{CXCL} 4 / \mathrm{PF} 4, \mathrm{ng} / \mathrm{ml}$ & $1.3 \pm 0.0^{\mathrm{a}, \mathrm{b}, \mathrm{c}}$ & $6,622.7 \pm 2,878.7^{\mathrm{d}}$ & $5,750.9 \pm 1,918.3^{\mathrm{b}, \mathrm{d}}$ & $3,941.0 \pm 1,825.3^{\mathrm{a}, \mathrm{d}}$ \\
\hline CCL5/RANTES, ng/ml & $1.76 \pm 0.02^{\mathrm{a}, \mathrm{b}, \mathrm{c}}$ & $415.8 \pm 111.0^{0 ., b, d}$ & $248.7 \pm 84.5^{\mathrm{cdd}}$ & $239.7 \pm 122.7^{\mathrm{c}, \mathrm{d}}$ \\
\hline
\end{tabular}

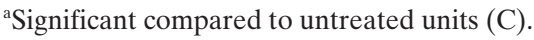

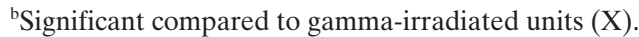

'Significant compared to PRT-treated units (M).

${ }^{\mathrm{d}}$ Significant compared to donor baseline.

\section{Discussion}

To evaluate whether nucleic acid-targeting PRT, like the Mirasol-PRT treatment, can reduce non-hemolytic and allergic transfusion reactions by reducing cytokine accumulation in PCs, we investigated the accumulation of several WBC- and PLT-derived cytokines during 7 days of storage in MirasolPRT-treated PLTs compared to untreated and gamma-irradiated units. The results obtained demonstrated alterations of PLT- but not of WBC-derived cytokines by Mirasol-PRT treatment and complemented a previous study investigating the effects of a psoralen-based PRT treatment (Intercept Blood System, Cerus Corp., Concorde, CA, USA) [13]. As previously described $[13,28]$, a low WBC content obtained by prestorage leukoreduction was associated with low levels of WBC-derived cytokines, also reported for buffy coat-derived PCs [29]. Mirasol-PRT was not associated with an increase or further decrease of WBC-derived cytokines throughout storage even for IL-1 and IL-8 derived from both, WBCs and PLTs $[26,27]$. This was in contrast to previously described respective data for psoralen-treated PLTs [13] demonstrating a significant increase of these cytokines during storage. However, technical differences cannot be entirely excluded as the source of this.

The levels of PLT-derived cytokines measured in our study are comparable to previous findings reporting wide ranges, especially for CXCL4 (PLT factor 4) [3, 29-35]. As reported previously, neither prestorage leukoreduction nor PRT treat- ment or gamma irradiation could prevent the accumulation of TGF- $\beta 1$, CCL5 (RANTES), and CXCL4 (PLT factor 4) [13, 33]. Compared to untreated or gamma-irradiated PCs, Mirasol-PRT treatment led to a significant elevation of soluble PLT-derived mediators. Cytokine accumulation in the supernatant of PCs results from PLT destruction and/or PLT activation leading to degranulation of PLT $\alpha$ granules and cytokine de novo synthesis [27]. The latter, however, requires optimal function of essential cell components like mitochondria and intact mRNA to serve as template for synthesis. Knowing that p-selectin is stored in the PLT $\alpha$ granules together with PLTassociated cytokines and growth factors, the levels of p-selectin can be expected to mirror the levels of cytokines released. The indicators for cell integrity, PLT count, and LDH release remained comparable between treated and untreated/gammairradiated units of our study indicating that the increased accumulation of PLT-derived cytokines after Mirasol-PRT treatment resulted mainly from PRT-induced PLT activation (as seen from the higher $\mathrm{p}$-selectin expression of $\mathrm{M}$ units) rather than PLT destruction. Additionally, the role of the storage medium used must also be taken into account when discussing cell lysis parameters. Studies comparing PAS III to $100 \%$ plasma, the storage medium of our study, showed higher levels of CCL5 (RANTES), CXCL4 (PLT factor 4), TGF- $\beta 1$, and PLT activation markers when PLTs were stored in PAS III [31, 35] or PAS II [36] rather than $100 \%$ plasma, indicating that suspension in $100 \%$ plasma protects PLTs from lysis. 


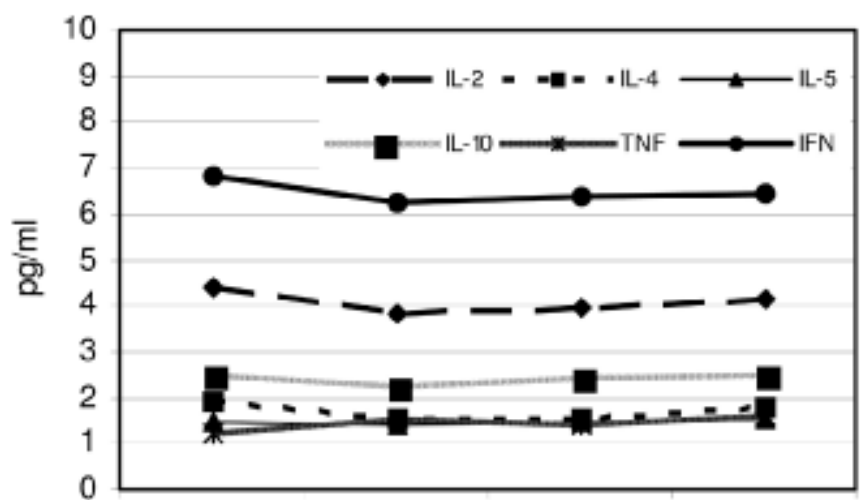

a

Day 0

Day 5

Day 7
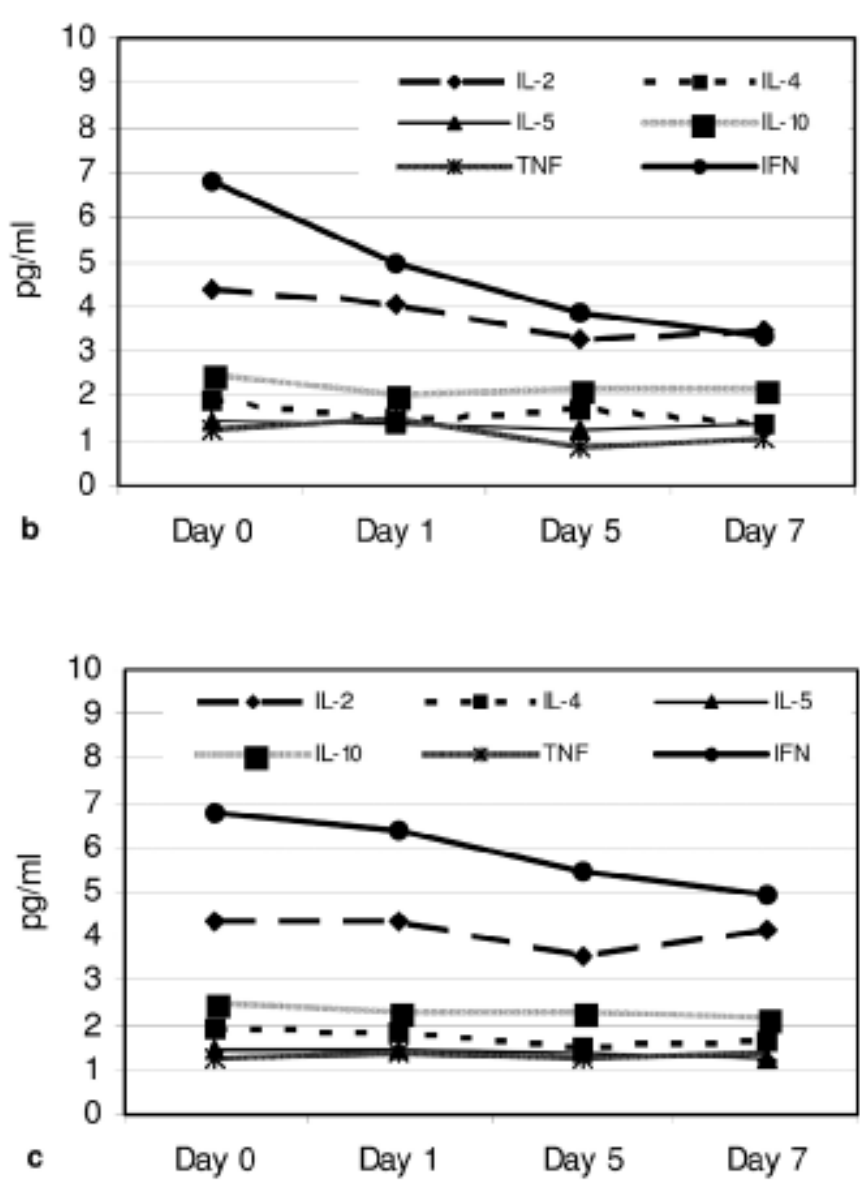

Fig. 1. WBC-derived Th- $1 / 2$ cytokine concentrations during 7 days of storage. The measured cytokine levels remained close to assay detection limits and donor-related baselines (day- 0 values) throughout 7 days of storage in all kinds of units. IFN- $\gamma$ showed a slight storage-related decrease but remained consistent in stored $\mathrm{M}$ units. After 7 days of storage, IL-4, TNF, and IFN- $\gamma$ were slightly but significantly elevated in M units relative to untreated controls. a Mirasol-PRT treatment, $\mathbf{b}$ remaining untreated controls, or $\mathbf{c}$ gamma irradiation.

Although it is well established that the frequency of febrile non-hemolytic transfusion reactions is reduced by prestorage leukoreduction, other transfusion reactions, predominantly allergic, still occur frequently [6-8]. Thus, PLT-derived soluble
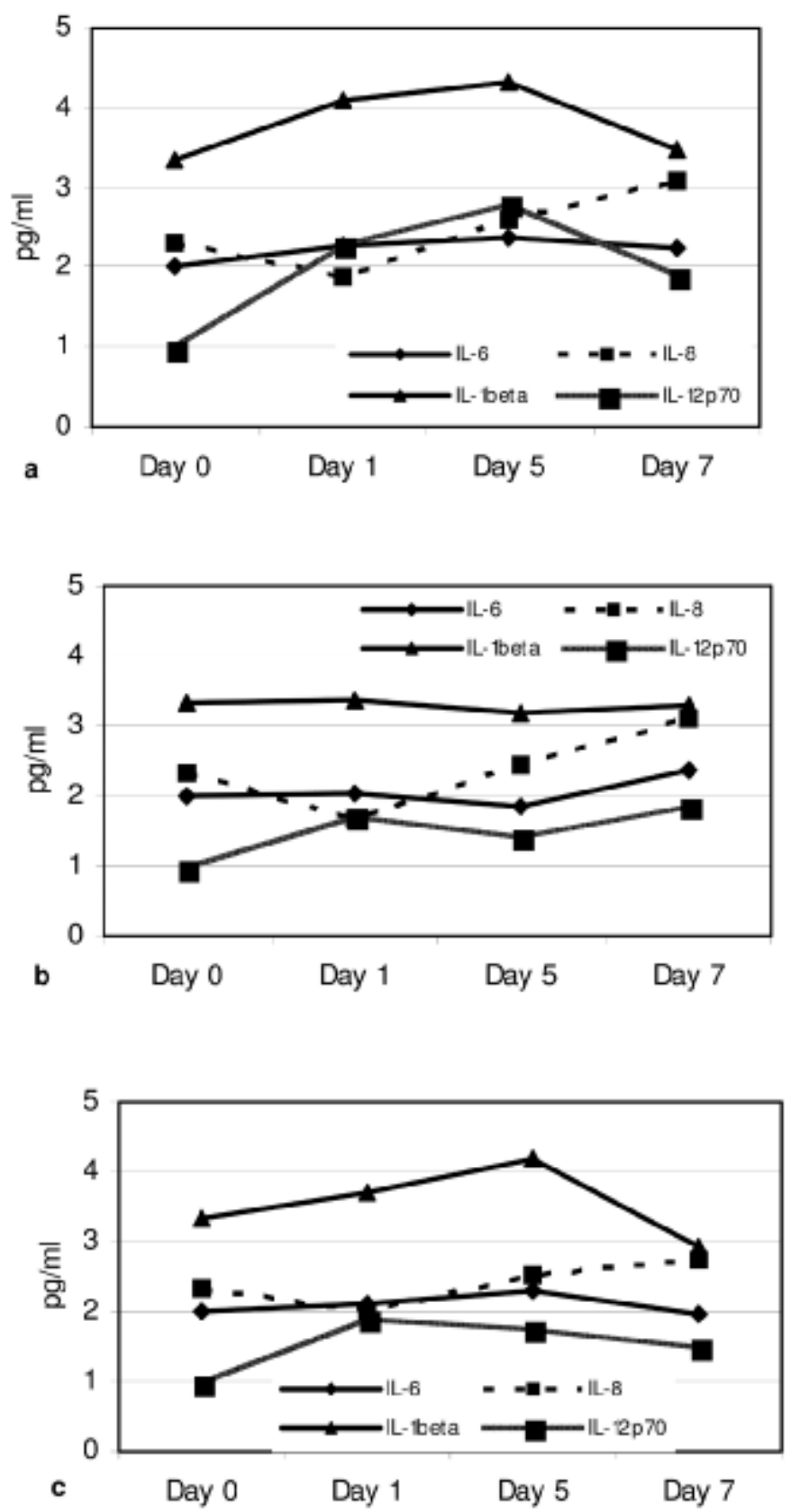

Fig. 2. WBC-derived inflammatory cytokine concentrations during 7 days of storage. As observed with Th- $1 / 2$ cytokines, the measured cytokine levels remained close to detection limits and donor-related baselines (day 0 values) throughout 7 days of storage. Only IL-8 exhibited a storage-related increase in all kind of units, slightly less pronounced in gamma-irradiated units. During storage, significant differences were not observed for any inflammatory cytokine, except for IL-12p70 which was slightly but significantly elevated in $\mathrm{M}$ units relative to gamma-irradiated units at day 5 of storage. a Mirasol-PRT treatment, $\mathbf{b}$ remaining untreated controls, or $\mathbf{c}$ gamma irradiation.

factors, rather than WBC-derived mediators, may be involved in adverse events after PLT transfusion. RANTES levels associated with allergic reactions have been reported to range from approximately 200 to $1,000 \mathrm{ng} / \mathrm{ml}$ with a median of 650 $\mathrm{ng} / \mathrm{ml}$ [3]. RANTES levels detected in Mirasol-PRT-treated 

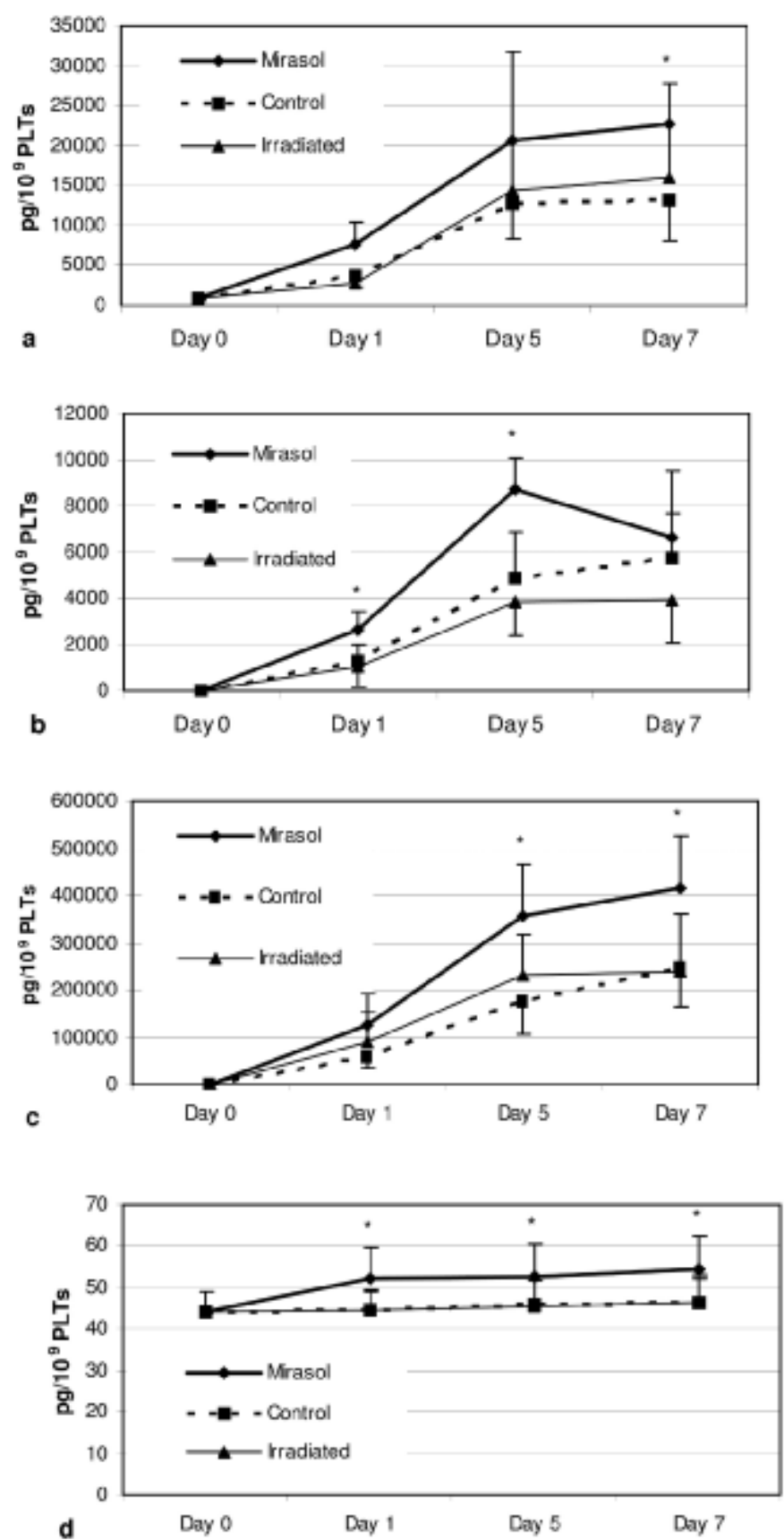

Fig. 3. PLT-derived cytokine concentrations corrected for PLT concentration. As observed with IL-8, levels of PLT-derived cytokines a TGF- $\beta$, b CXCL4 (PF4), and c CCL5 (RANTES) increased during 7 days of storage, except for d CCL3 (MIP $1 \alpha$ ) in C and X units. Significantly $(* p<0.05)$ higher accumulation rates were observed after MirasolPRT treatment relative to $\mathrm{C}$ and $\mathrm{X}$ units.

units were elevated (median of $360 \mathrm{ng} / \mathrm{ml}$ for 5 -days-stored PLTs) compared to untreated control units (median of 195 $\mathrm{ng} / \mathrm{ml}$ ), but within a range where the risk of inducing an allergic transfusion reaction may be low. Mean levels of RANTES reported for 7-day-stored psoralen-treated PLTs (470-500 ng/ $\mathrm{ml}$ ) [13] were well within the range of $300-670 \mathrm{ng} / \mathrm{ml}$ observed in our study for 7-day-stored riboflavin-treated PLTs. Accordingly, the overall adverse event rate obtained in clinical trials
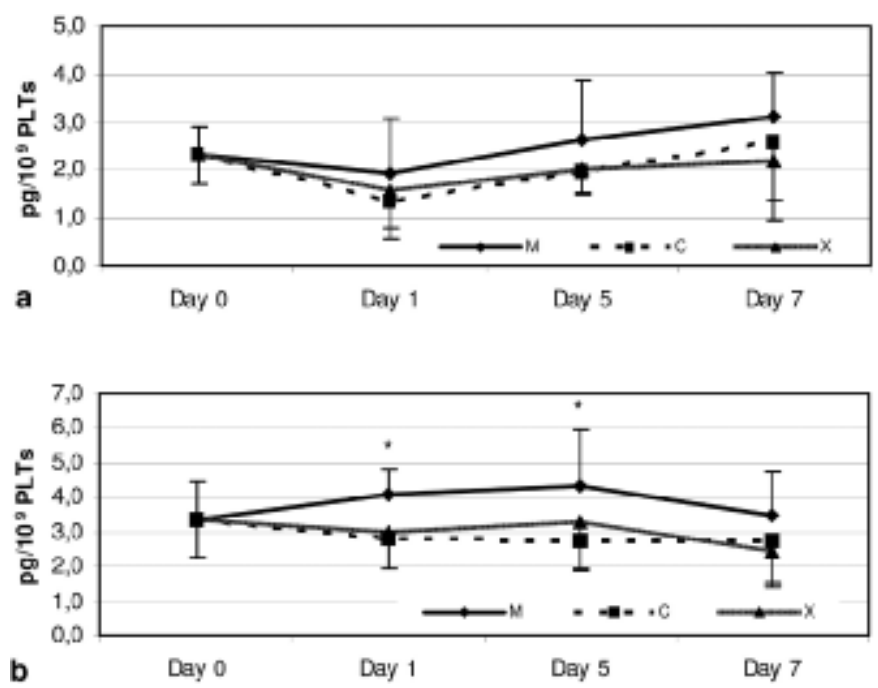

Fig. 4. Storage-related a IL-8 (CXCL8) and b IL-1 $1 \beta$ levels corrected for PLT count. No significant differences were observed between $\mathrm{M}$ units and their counterparts, except for IL-1 $\beta$ at storage days 1 and 5 with slightly but significantly elevated values $(* \mathrm{p}<0.05)$ in $\mathrm{M}$ units.

on psoralen-treated PLTs was not significantly different from untreated units $[37,38]$ reinforcing the above mentioned observation.

In agreement with Apelseth et al. [13], we conclude that PLTs are the main source of soluble mediators accumulated in leukoreduced PCs. WBC-associated cytokines could be detected at very low levels and did not increase during storage. Independent of treatment, relatively high concentrations of PLT-derived cytokines accumulated during storage reaching a plateau after 5-7 days. Like other PRT methods, treatment with riboflavin in combination with UV light appeared to increase the accumulation of PLT-derived cytokines, most likely due to accelerated PLT activation. Since the impact of PLT-derived chemokines such as CCL5 (RANTES) as major mediators of transfusion reactions is conflicting, more appropriate clinical studies on different PRTs are highly desirable to outline the role of PLT-derived mediators or plasma reduction and the frequency of adverse events after PLT transfusion.

\section{Acknowledgements}

We would like to thank Dr. Maike Rieks (scientific coworker of BD Biosciences), Margret Schlütz (technician of the Department of Transfusion Medicine of the University of Cologne) for technical help, and elaborate and kind assistance during cytokine measurements. We also thank Inge Reynaerts (Caridian BCT Biotechnologies, Lakewood, CO, USA) for assistance in data collection, Raymond P. Goodrich, Susanne Marschner (Caridian BCT Biotechnologies) and Stef De Reys (Caridian BCT Biotechnologies, Zeventem, Belgium) for excellent scientific support.

\section{Disclosure}

The authors declared no conflict of interest. 


\section{References}

1 Heddle NM, Klama L, Meyer R, Walker I, Boshkov L, Roberts R, Chambers S, Podlosky L, O'Hosky P, Levine M: A randomized controlled trial comparing plasma removal with white cell reduction to prevent reactions to platelets. Transfusion 1999;39:231-238.

$\checkmark 2$ Heddle NM, Klama I, Singer J, Richards C, Fedak P, Walker I, Kelton JG: The role of the plasma from platelet concentrates in transfusion reactions. N Eng J Med 1994:331:625-628.

3 Klüter H, Bubel S, Kirchner H, Wilhelm D: Febrile and allergic transfusion reactions after the transfusion of white cell-poor platelet preparations. Transfusion 1999;39:1179-1184.

$\checkmark 4$ Spiess BD, Royston D, Levy JH, Fitch J, Dietrich W, Body S, Murkin J, Nadel A: Platelet transfusions during coronary artery bypass graft surgery are associated with serious adverse outcomes. Transfusion 2004;44:1143-1148.

5 Lösche W, Heptinstall S: Value of platelet activation markers as prothrombotic risk indicators. Transfus med Hemother 2007:34:34-42.

6 Paglino JC, Pomper GJ, Fisch GS, Champion MH, Snyder EL: Reduction of febrile but not allergic reactions to RBCs and platelets after conversion to universal prestorage leukoreduction. Transfusion 2004:44:16-24.

7 Yazer MH, Podlosky L, Clarke G, Nahirniak SM: The effect of prestorage WBC reduction on the rates of febrile nonhemolytic transfusion reactions to platelet concentrates and RBC. Transfusion 2004;44:10-15.

$>8$ Heddle NM, Blajchman MA, Meyer RM, Lipton JH, Walker IR, Sher GD, Constantini LA, Patterson B, Roberts RS, Thorpe KE, Levine MN A randomized controlled trial comparing the frequency of acute reactions to plasma-removed platelets and prestorage WBC-reduced platelets. Transfusion 2002;42:556-566.

-9 Wakamoto S, Fujihara M, Kuzuma K, Sato S, Kato T, Naohara T, Kasai M, Sawada K, Kobayashi R, Kudoh T, Ikebuchi K, Azuma H, Ikeda $\mathrm{H}$ : Biologic activity of RANTES in apheresis PLT concentrates and its involvement in nonhemolytic transfusion reactions. Transfusion 2003;43:10381046.

10 Alam R, Stafford S, Forsythe P, Harrison R, Faubion D, Lett-Brown MA, Grant JA: RANTES is a chemotactic and activating factor for human eosinophils. J Immunol 1993;150:3442-3448.

11 Rot A, Krieger M, Brunner T, Bischoff SC, Schall TJ, Dahinden CA: RANTES and macrophage inflammatory protein 1 alpha induce the migration and activation of normal human eosinophil granulocytes. J Exp Med 1992;176:1489-1495.

- 12 Kuna P, Reddigari SR, Schall TJ, Rucinski D, Viksman MY, Kaplan AP: RANTES, a monocyte and $\mathrm{T}$ lymphocyte chemotactic cytokine releases histamine from human basophils. J Immunol 1992; 149:636-642.

13 Apelseth TO, Hervig TA, Wetzel-Larsen T, Bruserud $\varnothing$ : Cytokine accumulation in photochemically treated and gamma-irradiated platelet concentrates during storage. Transfusion 2006;46: 800-810.
14 Hei DJ, Grass J, Lin L, Corash L, Cimino G: Elimination of cytokine production in stored platelet concentrate aliquots by photochemical treatment with psoralen plus ultraviolet A light. Transfusion 1999:39:239-248.

15 Fast LD, DiLeone G, Li J, Goodrich R: Functional inactivation of white blood cells by Mirasol treatment. Transfusion 2006;4446:642-648.

16 Sottile J, Mosher DF, Fullenweider J, George JN: Human platelets contain mRNA transcripts for platelet factor 4 and actin. Thromb Haemost 1989;62:1100-1102.

17 Bruce IJ, Kerry R: The effect of chloramphenicol and cycloheximide on platelet aggregation and synthesis. Biochem Pharmacol 1987;36:1769-1773.

18 Caspari G, Gerlich WH, Kiefel V, Gürtler L: Pathogen inactivation of cellular blood products - still plenty of reason to be careful. Transfus Med Hemother 2005;32:258-260.

19 German Medical Association and Paul-EhrlichInstitute: Guidelines for the Collection of Blood and Blood Components and the Usage of Blood Products (Hemotherapy), rev. ed. Cologne, Deutscher Ärzteverlag, 2005.

20 Council of Europe: Guide to the Preparation, Use and Quality Assurance of Blood Components. 13th ed. Strassbourg, France, Council of Europe Publishing, 2007.

21 Li J, Lockerbie O, De Korte D, Rice J, McLean R, Goodrich RP: Evaluation of platelet mitochondria integrity after treatment with Mirasol pathogen reduction technology. Transfusion 2005;45:920-926.

22 Perez-Pujol S, Tonda R, Lozano M, Fuste B, Lopez-Vilchez I, Galan AM, Li J, Goodrich R, Escolar G: Effects of a new pathogen-reduction technology (Mirasol PRT) on functional aspects of platelet concentrates. Transfusion 2005;45:911919.

23 Goodrich RP, Li J, Pieters H, Crookes R, Roodt J, Heyns AP: Correlation of in vitro platelet quality measurements with in vivo platelet viability in human subjects. Vox Sang 2006;90:279-285.

24 Li J, De Korte D, Woolum MD, Ruane PH, Keil SD, Lockerbie O, McLean R, Goodrich RP: Pathogen reduction of buffy coat platelet concentrates using riboflavin and light: comparisons with pathogen-reduction technology-treated apheresis platelet products. Vox Sang 2004;87:82-90.

25 Picker SM, Speer R, Gathof BS: Functional characteristics of buffy-coat PLTs photochemically treated with amotosalen- $\mathrm{HCl}$ for pathogen inactivation. Transfusion 2004;44:320-329.

26 Gear AR, Camerini D: Platelet chemokines and chemokine receptors: linking hemostasis, inflammation, and host defense. Microcirculation 2003; 10:335-350.

27 Lindemann S, Tolley ND, Dixon DA, McIntyre TM, Prescott SM, Zimmerman GA, Weyrich AS: Activated platelets mediate signaling by regulated interleukin 1 beta synthesis. J Cell Biol 2001;154: $485-490$.
8 Hartwig D, Härtel C, Hennig H, Müller-Steinhardt M, Schlenke P, Klüter H: Evidence for de novo synthesis of cytokines and chemokines in platelet concentrates. Vox Sang 2002;82:182-190.

29 Cazenave JP, Aleil B, Wiesel ML, Laforêt M, Isola $\mathrm{H}$ : In vitro evaluation of pooled buffy coat platelets treated with photochemical pathogen inactivation using amotosalen. Vox Sang 2004;86:201202.

30 Wadhwa M, Krailadsiri P, Dilger P, Gaines Das $\mathrm{R}$, Seghatchian MJ, Thorpe R: Cytokine levels as performance indicators for white blood cell reduction of platelet concentrates. Vox Sang 2002;83: 125-136.

31 Cardigan R, Sutherland J, Wadhwa M, Dilger P, Thorpe R: The influence of platelet additive solutions on cytokine levels and complement activation in platelet concentrates during storage. Vox Sang 2003;84:28-35.

32 Böck M, Rahrig S, Kunz D, Lutze G, Heim MU: Platelet concentrates derived from buffy coat and apheresis: biochemical and functional differences. Transfus Med 2002;12:317-324.

33 Fujihara M, Ikebuchi K, Wakamoto S, Sekiguchi S: Effects of filtration and gamma radiation on the accumulation of RANTES and transforming growth factor beta 1 in apheresis platelet concentrates during storage. Transfusion 1999;39:498505.

34 Turner CP, Sutherland J, Wadhwa M, Dilger P, Cardigan R: In vitro function of platelet concentrates prepared after filtration of whole blood or buffy coat pools. Vox Sang 2005;88:164-171.

35 Shanwell A, Falker C, Gulliksson H: Storage of platelets in additive solutions. The effects of magnesium and potassium on the release of RANTES, beta-thromboglobulin, platelet factor 4 and interleukin-7, during storage. Vox Sang 2003;85:206212.

36 de Wildt-Eggen J, Schrijver JG, Smid WM, Joie $\mathrm{M}$, Bollinne V, Bins M: Platelets stored in a new generation container. Differences between plasma and platelet additive solution II. Vox Sang 1998;75:218-223.

37 Van Rhenen D, Gulliksson H, Cazenave JP, Pamphilon D, Ljungman P, Klüter $\mathrm{H}$, Vermeij $\mathrm{H}$, Kappers-Klunne M, de Greef G, Laforet M, Lioure B, Davis K, Marblie S, Mayaudon V, Flament J, Conlan M, Lin L, Metzel P, Buchholz D, Corash L: Transfusion of pooled buffy-coat platelet components prepared with photochemical pathogen inactivation treatment: the euroSPRITE trial. Blood 2003;101:2426-2433.

38 Mc Cullough J, Vesole DH, Benjamin RJ, Slichter SJ, Pineda A, Snyder E, Stadtmauer EA, LopezPlaza I, Coutre S, Strauss RG, Goodnough LT, Fridey JL, Raife T, Cable R, Murphy S, Howard F 4th, Davis K, Lin JS, Metzel P, Corash L, Koutsoukos A, Lin L, Buchholz DJ, Conlan MG: Therapeutic efficacy and safety of platelets treated with a photochemical process for pathogen inactivation: the SPRINT Trial. Blood 2004;104:1534-1541. 